\title{
Production of recycled manure solids for bedding in Canadian dairy farms: I. Solid-liquid separation
}

\author{
S. Fournel, ${ }^{1 *}$ S. Godbout, ${ }^{2}$ P. Ruel, ${ }^{3}$ A. Fortin, ${ }^{2}$ M. Généreux, ${ }^{2}$ C. Côté, ${ }^{2}$ C. Landry, ${ }^{2}$ and D. Pellerin ${ }^{1}$ \\ ${ }^{1}$ Département des Sciences Animales, Université Laval, Québec City, Québec, Canada G1V 0A6 \\ ${ }^{2}$ Research and Development Institute for the Agri-Environment (IRDA), Québec City, Québec, Canada G1P 3W8 \\ ${ }^{3}$ Centre de Recherche en Sciences Animales de Deschambault (CRSAD), Deschambault, Québec, Canada G0A 1S0
}

\section{ABSTRACT}

Canadian dairy producers have an increasing interest in recycled manure solids (RMS) as bedding material because of reduced availability of traditional bedding resources. Information regarding methods to obtain RMS and composition of RMS is very limited. Hence, a 2-part investigation was developed to compare the performances of 3 mechanical solid-liquid manure separators (part I) and 4 composting methods (part II; companion paper in this issue) for the production of high quality RMS. In this first study, a roller press, a screw press, and a decanter centrifuge were tested for the separation of slurry manure from a commercial dairy farm. During the experiment, the quantity of slurry manure processed and the volume and mass of the liquid and solid fractions were measured. The energy consumption of each separator was recorded, and samples of the slurry, liquid, and solid effluents were collected for analysis. The type of separator did not significantly influence the chemical and bacteriological composition of RMS produced. The choice of a separator for Canadian dairy producers should thus be based on the equipment cost and its capacity, targeted solids dry matter (DM) content and structure, and fertilizing quality of the separated liquid. The decanter centrifuge produced the solid phase with the highest DM and best separation efficiencies for DM, N, and P. However, its low production capacity $\left(1.5 \mathrm{~m}^{3} / \mathrm{h}\right.$ vs. $\left.9.1-20.3 \mathrm{~m}^{3} / \mathrm{h}\right)$ combined with its high acquisition cost (Can $\$ 145,000$ vs. Can $\$ 75,000)$ and energy consumption $(4.99 \mathrm{kWh} /$ $\mathrm{m}^{3}$ vs. $0.10-0.35 \mathrm{kWh} / \mathrm{m}^{3}$ ) reduce its technical and profitability values. Besides, the centrifuge produced fine structured RMS and a low-quality liquid fraction, not suitable as dairy cow bedding and fertilizer, respectively. Both presses reached acceptable production capacity at a minimal operation cost. However, the

Received April 23, 2018.

Accepted October 3, 2018.

*Corresponding author: sebastien.fournel.1@ulaval.ca poor performance in terms of DM $(25 \%)$ of the model of screw press used in this study produced RMS unsuitable for immediate use without further processing. The model of roller press used in this study had the advantages of almost reaching the recommended DM content in RMS (>34\%), being flexible in terms of inputs, and producing fluffy RMS. Nevertheless, its compression process seemed to allow greater passage of solids into the liquid fraction compared with the screw press. Part II of this work explores different composting methods to reduce the health risks associated with screw-pressed RMS before their use as bedding.

Key words: cattle slurry, separated solid fraction, bedding characteristics, bacterial count

\section{INTRODUCTION}

Reduced availability and increased cost of common bedding materials have prompted many dairy producers in North America to search for possible alternatives (Harrison et al., 2008; Husfeldt et al., 2012). The interest in recycled manure solids (RMS) as a substitute bedding source has thus increased due to their high on-site availability and benefits for cow comfort (Garcia and Diaz-Royón, 2014; Leach et al., 2015; House, 2016). However, several studies reported that RMS have a greater ability to promote the growth of environmental bacteria than other bedding products (Godden et al., 2008; Rowbotham and Ruegg, 2016; Bradley et al., 2018). As a result, dairy stakeholders are skeptical about using RMS successfully as bedding (Meyer et al., 2007; Harrison et al., 2008; Husfeldt et al., 2012), especially in wet and cold areas such as Canada (Leach et al., 2015). Moreover, reliable research data on the use of RMS as bedding material for dairy cows, including methods of obtaining RMS, chemical and bacteriological characteristics of RMS, and their effect on milk quality and animal welfare, are scarce (Gooch et al., 2005; Leach et al., 2015; Bradley et al., 2018). Before evaluating the effects of RMS bedding on Canadian dairy farms, the first step is to produce high quality RMS with a minimal pathogen load. 
Recycled manure solids are a DM- and nutrientrich fraction obtained by mechanical or gravitational separation of slurry manure removed from dairy cows' housing systems (Figure 1). Solid-liquid separation of dairy manure can be accomplished by several methods including stationary, vibrating, or rotating screens, screw or roller presses, and decanter centrifuges (Zhang and Westerman, 1997; Ford and Fleming, 2002; Katers et al., 2003). Screens are the most extensively tested separators, but they generally work better with manure containing a low DM level $(<5 \%)$ because of potential plugging. In contrast, presses and centrifuges operate well when manure contains a high amount of DM and can reach higher separation efficiencies and produce drier solids than screen separators (Zhang and Westerman, 1997; Christensen et al., 2013). In recent years, screw separators have been described as the main equipment used for producing RMS on dairy farms in the Midwestern United States (Husfeldt et al., 2012), in the United Kingdom (Bradley et al., 2014), in the Netherlands (Valacon-Dairy, 2014), and in Ontario, Canada (House, 2016). The roller press is also commonly used in those countries (House, 2012), whereas decanter centrifuges are especially used on large pig farms in Asia (Hjorth et al., 2010).

For the production of RMS, the aim is to separate as much structure-rich material from the slurry manure as possible (Valacon-Dairy, 2014). When selecting a separation technology, producers should also consider the ability of RMS to promote growth of environmental pathogens, which is influenced by physico-chemical properties of the material such as moisture content (Godden et al., 2008; Sorter et al., 2014). Both types of presses and centrifuges produce a bedding product with a DM content of 16 to $39 \%$ (Godbout et al., 2002; Harrison et al., 2008; Timms, 2008). Great variability is present in the efficiency of DM removal between the separators: $16-78 \%$ for screw presses, $14-40 \%$ for roller presses, and $25-77 \%$ for decanter centrifuges (Godbout et al., 2002; Gooch et al., 2005; Cocolo et al., 2012). In terms of bacterial counts after separation, Rowbotham and Ruegg (2016) and the studies reviewed by Leach et al. (2015) indicate large ranges of values for several pathogens with screw presses.

At this time, it is hard for Canadian dairy producers to identify the best equipment to obtain RMS, considering that the different separator types have never been tested and compared using the same manure as influent. Therefore, the present article aims to assess the performance of 3 solid-liquid separators (screw press, roller press, and decanter centrifuge) for the production of high quality RMS bedding. Physical, chemical, and bacteriological characteristics of the slurry, liquid, and solid effluents are also assessed to analyze the influence of influent properties and the repartition of elements between liquid and solid fractions that could affect the fertilizing quality of liquid manure.

\section{MATERIALS AND METHODS}

\section{Tested Separators}

The first separator was a decanter centrifuge (B/ DF 300 model, Bargam, Cingoly, Italy; approximate original cost $=$ Can $\$ 145,000)$ consisting of a drum rotating at high speed so that the centrifugal force results in separation of the product into a solid part that is conveyed to an auger discharge area and a liquid part. An electric motor $(7.5 \mathrm{~kW})$, equipped with a hydromechanical coupling, controls the rotation of the drum and auger through a drive belt.

The second separator was a roller press (XPress model, GEA Houle, Drummondville, QC, Canada; approximate original cost $=\operatorname{Can} \$ 75,000)$ consisting of an inlet hopper followed by 2 pairs of rollers in cascading configuration. Each set of rollers contains a bottom roller, which is a screen roller with calibrated openings that allows liquid to be drained out while the manure is

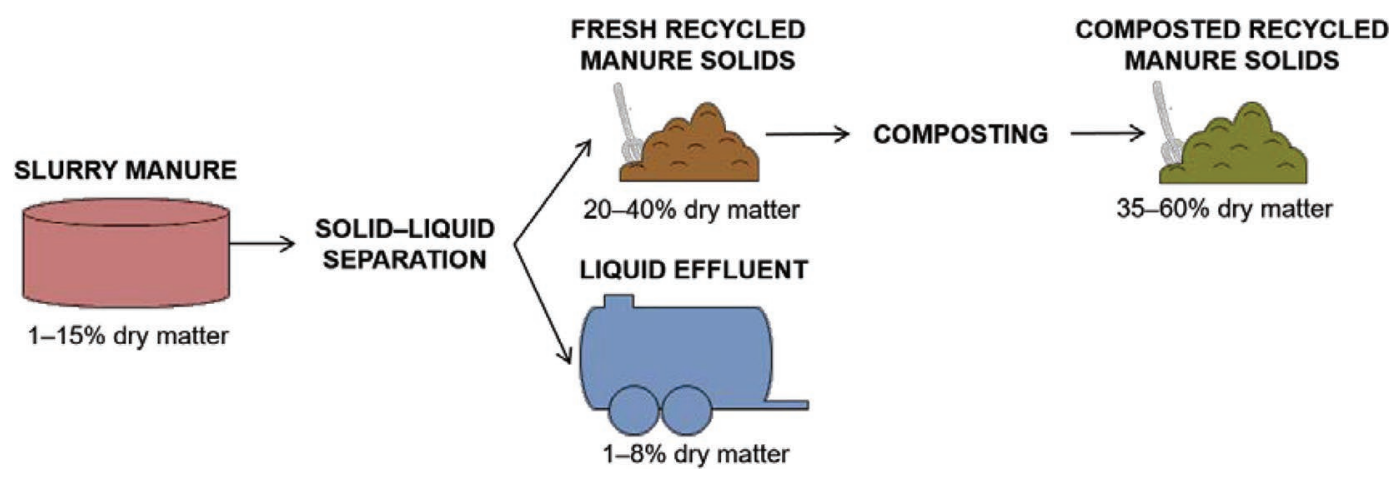

Figure 1. Typical flowchart of recycled manure solids production. 
squeezed between the rollers, and an upper roller, which is surface coated with rubber allowing adherence on the screen roller and ensuring excellent fiber compression. Bottom rollers are driven by a $1.1-\mathrm{kW}$ electrical motor. Because 2 pneumatic springs maintain constant pressure on each upper roller, the rubber rollers are driven by the screen rollers. The primary pair of rollers has a length of $1.2 \mathrm{~m}$ and is designed to maximize the extraction of water from solids at low pressure applied on the rollers (maximum of $276 \mathrm{kPa}$ or $40 \mathrm{psi}$ ). The secondary pair of rollers has a length of $0.6 \mathrm{~m}$ and is designed to maximize the extraction of water from solids at high pressure applied on the rollers (maximum of $483 \mathrm{kPa}$ or $70 \mathrm{psi}$ ). A nylon scraper removes residual fiber from the last screen roller after compression.

The third separator was a screw press (FAN model PSS 2-520, Bauer Group, Michigan City, IN; approximate original cost $=$ Can $\$ 75,000)$ consisting of an electrical motor $(3.7 \mathrm{~kW})$ driving a stainless steel auger. This auger rotates counter-clockwise conveying the slurry into the screw press section of the separator. It consists of a stationary cylindrical steel screen with 1 -mm openings. Free gravity liquid is filtered out in the screen area and exits through the effluent pipe. Bonded liquid that is attached to the solids is squeezed out by the compression that occurs within the last 2 turns of the auger. At the end of the auger, a plug of solids is created to provide resistance to the horizontal movement of the solids. The squeezed solids pass through a mouthpiece cylinder, consisting of a cylinder of equal diameter to the screen and a weight arm attachment with flaps controlling the pressure exerted on the plug.

\section{Experimental Setup}

A 2-wk experiment was conducted from May 23 to June 6, 2017, at the Centre de Recherche en Sciences Animales de Deschambault (CRSAD, Deschambault, QC, Canada). The experiment mainly took place under a semi-circular, membrane-covered building where the screw and roller presses were installed to be protected from bad weather. The decanter centrifuge was installed in a trailer. A schematic view of the setup is presented in Figure 2.

Between the hoop structure and the centrifuge trailer, a temporary $5.5-\mathrm{m}$ diameter slurry tank was assembled on a gravel base to contain up to $51.5 \mathrm{~m}^{3}$ of fresh manure. The sidewalls were made of recycled cor-

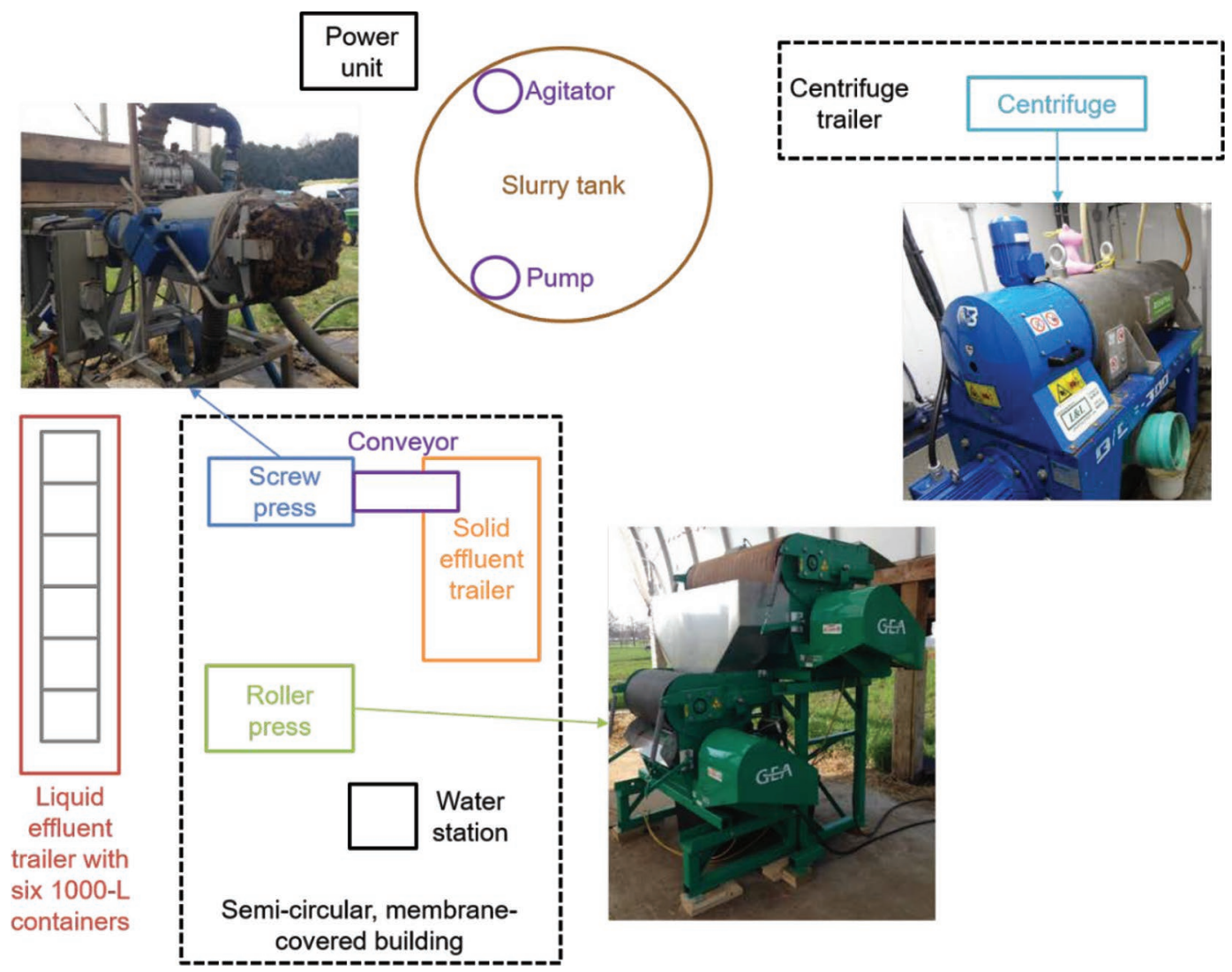

Figure 2. Schematic view of the experimental setup. 
rugated steel silo sheets and a geosynthetic membrane coated the inside of the reservoir. A manure agitator (AE-7-1/2-7 model, J. Houle \& Fils Inc., Drummondville, QC, Canada) was installed on the edge of the tank to stir the slurry manure for the duration of each experimental test. A centrifugal pump (HS2037BHF model, Goulds Water Technology, Seneca Falls, NY) was placed on a concrete plate at the bottom of the tank to feed each separator during tests. Long $5-\mathrm{cm}-$ diameter pipes transported the slurry manure from the pump to the separators and from the separator overflows to the tank.

At the exit of the screw and roller presses, the solid effluent dropped onto a belt conveyor before accumulating in a tractor-pulled trailer. For the decanter centrifuge, the solid effluent was removed with an auger screw before falling in the same trailer. Liquid effluent was evacuated from each separator by gravity to a $75-\mathrm{L}$ plastic basin from which it was pumped to six 1,000-L containers on a flat tractor-pulled trailer.

A power unit (QAS 150T3 model, Atlas Copco, Rock Hill, SC) consisting of a $120-\mathrm{kW}$ generator delivering 3 -phase voltage $(600 \mathrm{~V})$ was used to provide electricity to the separators, agitator, pumps, and computers. A water station allowed manual cleaning of the equipment.

\section{Experimental Design}

At the beginning of each week, the slurry tank was filled with fresh manure coming from the in-barn storage pit of a nearby dairy farm using RMS for $5 \mathrm{yr}$. During the following days, the 3 separators were tested one at a time at a 2 -d interval thus allowing $48 \mathrm{~h}$ between tests to perform the bacteriological analysis (see next subsection). The testing order was determined by drawing lots. At the end of the experiment, 2 series of tests with manure of a maximum of $7 \mathrm{~d}$ of age had been completed.

Before each experimental test, slurry manure in the tank was agitated for at least $2 \mathrm{~h}$. During that time, the pipes linking the pump were connected to the tested separator, the conveyor or auger screw was placed at the exit for the solid effluent, and both trailers were moved near the separator to collect their respective manure fraction. Adjustments (e.g., weight on arm attachment, roller pressure, or centrifuge inflow) on each separator were also made according to preliminary tests conducted to determine the best separation parameters.

Each experimental test lasted the time necessary for the separator to produce $0.5 \mathrm{~m}^{3}$ of solids (between 15 and 100 min depending on the separator capacity). At the end of each day of test with the roller press or the centrifuge, the separator was washed with water. The screw press was not cleaned between each use because a plug of solids was needed at the exit for the machine to work properly.

\section{Data Collection and Analytical Procedures}

During each experimental test, the energy consumption of the separator was recorded using split core current transformers (Dent Instruments, Bend, OR) connected to a power submeter (PowerScout 3037 model, Dent Instruments) linked to a microcomputer (X8 model, Pipo, Shenzhen, China). Three 0.5-L sampling bottles of each constituent (slurry, liquid, and solid effluents) and one 4-L airtight bag of solids were collected at min 5,10 , and 15 . The slurry samples contained the manure collected by a $0.1-\mathrm{L}$ plastic beaker attached to the end of a rod immersed several times in the tank near the submerged pump. The liquid bottles were filled with another 0.1-L plastic beaker immerged several times in the 75 -L plastic basin positioned directly after the free gravity liquid effluent pipe of the separator monitored. The solids samples (bottle and bag) were composed of several handfuls of fresh RMS grabbed at the end of the conveyor for the screw and roller presses or at the end of the auger screw for the centrifuge. Each sample was kept at $4^{\circ} \mathrm{C}$ until analysis.

Physico-chemical analysis was performed within $2 \mathrm{wk}$ of sampling following the methods described in Table 1. Bacteriological analysis was performed within 48 h of sampling and counts of Escherichia coli, Klebsiella spp., Enterococcus spp., Staphylococcus spp., and Streptococcus spp. were determined as follows. First, $225 \mathrm{~mL}$ of $0.1 \%$ tryptone-salt broth was added to 25 $\mathrm{g}$ of solid material or $25 \mathrm{~mL}$ of liquid material and thoroughly mixed in a stomacher for $60 \mathrm{~s}$. One milliliter was transferred into $9 \mathrm{~mL}$ of $0.1 \%$ tryptone-salt broth and a series of 1:10 dilutions were completed. For each dilution, $1 \mathrm{~mL}$ was plated on a $3 \mathrm{M}$ Petrifilm E. coli/ coliforms count plate (3M Microbiology Products, St. Paul, MN) according to the manufacturer's instructions for E. coli counts. Fifty microliters of each dilution was also directly plated on MacConkey no. 3 (Oxoid Ltd., Basingstoke, UK), m-enterococcus (BD Difco, Sparks, MD), Vogel-Johnson (BD Difco), and modified Edwards (Oxoid Ltd.) agars for analysis of the other 4 above-mentioned bacteria. MacConkey, Vogel-Johnson, and Edwards agars were incubated at $35^{\circ} \mathrm{C}$ for $24 \mathrm{~h}$, and dilutions presenting between 30 and $300 \mathrm{cfu}$ were counted. The $3 \mathrm{M}$ Petrifilm and m-enterococcus plates were incubated at $35^{\circ} \mathrm{C}$ for $48 \mathrm{~h}$. For each analytical method, negative, positive, and matrix controls were properly conducted with each batch of samples tested. For positive and matrix controls, American Type Culture Collection standard strains (E. coli 25922, Kleb- 
Table 1. Methods used for physical, chemical, and bacteriological analyses

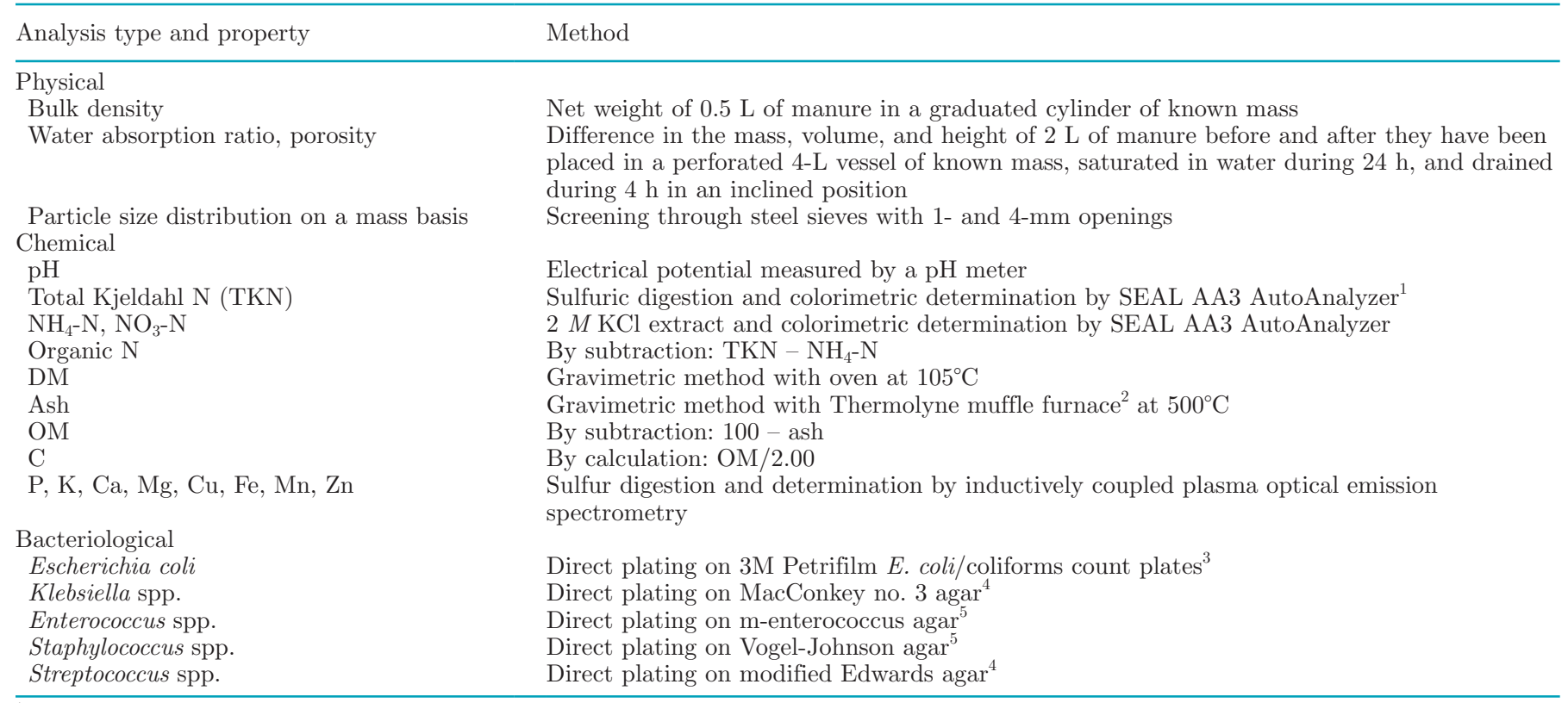

${ }^{1}$ Folio Instruments, Kitchener, ON, Canada.

${ }^{2}$ Thermo Fisher Scientific, Waltham, Massachusetts.

${ }^{3} 3 \mathrm{M}$ Microbiology Products, St. Paul, Minnesota.

${ }^{4}$ Oxoid Ltd., Basingstoke, United Kingdom.

${ }^{5}$ BD Difco, Sparks, Maryland.

siella pneumoniae 13883, Enterococcus faecalis 29212, Staphylococcus aureus 28213) and a strain of Strep. agalactiae previously isolated from a fecal sample were added in $0.1 \%$ tryptone-salt broth and plated and incubated on separated agars as mentioned for samples. Bacteriological analyses are also summarized in Table 1.

\section{Calculations}

Mass and volume flow rates for each manure fraction were determined using different methods. The level of slurry manure in the tank was measured before and after each experiment to determine the total volume of manure processed. The mass flow rate was calculated knowing the density of the influent product through the physical analysis. Liquid and solid effluents' mass flow rates were determined by subtracting the tare weights of the trailers from their final weights (measured on a 3025MPV scale, Fairbanks, Kansas City, MO) and dividing the result by the running time given by a stopwatch. Liquid effluent volume flow rate was measured using the gradations on the cubic meter containers. Solid effluent volume flow rate was calculated knowing the density of the constituent through the physical analysis (see Table 1 for methods).
To compare the characteristics of 3 products with different DM, which also varied from one separator to another, concentrations were reported on a dry basis as in Cole (2015). Bacterial counts were also log-transformed and divided by their bulk density (liquid samples only) to be expressed in $\log _{10} \mathrm{cfu} / \mathrm{g}$ of DM. Energy consumption was determined using the electrical power equation. The separation efficiency, which is the ratio of the total mass recovery of a given component (DM or nutrients) in the solid phase as a proportion of the total input of that component, was calculated according to the method described by Cocolo et al. (2012). In fact, this index expresses the distribution of a specific compound between the liquid and solid fractions.

\section{Statistical Analyses}

A linear mixed model (MIXED procedure, SAS v9.4, SAS Institute Inc., Cary, NC) was built to assess the performances of the 3 solid-liquid manure separators. The separator, the experimental week, and the interaction separator by week were the fixed explanatory variables used in the model. Parameters evaluated during physical, chemical, and bacteriological laboratory procedures were analyzed using sample within test as the experimental unit with test as a random effect. 
$F$-test values, means, standard deviations, and $95 \%$ confidence intervals for all fixed effects were calculated. Multiple comparisons of least squares means ( $t$-test) between separators for all weeks and each week were also completed. Normality and homogeneity of variance were visually evaluated using residual plots.

\section{RESULTS AND DISCUSSION}

\section{Dry Matter Content, Separation Capacity, and Energy Consumption}

Slurry Manure. The influent slurry DM content significantly varied $(P<0.001)$ between periods reaching 6.18 and $7.86 \%$ during wk 1 and 2, respectively (Table 2). Because we imported the slurry twice from the same dairy farm, this DM difference was likely due to more water entering the slurry pit during the first week as a result of more water used to clean barn floors. Within a week, however, no significant difference $(P>$ $0.05)$ was present between the separators in terms of slurry DM percentage. This result demonstrates that the 7-d storage under natural conditions did not significantly alter slurry DM content. Obviously, this period was not long enough for the transformation of organic material into gases to occur (Møller et al., 2002).

The slurry DM variation seemed to influence the treatment capacity of the separator and its energy consumption (Figure 3). In this study, we observed a 13 to $30 \%$ decrease in volume flow rate for the influent slurry and a 23 to $85 \%$ increase in energy use from wk 1 to 2 . These results are consistent with the conclusion of Zhang and Westerman (1997) that the main characteristic parameters of animal manure affecting the solid-liquid separation performance include particle size distribution and initial TS content.

Overall, the screw press had the greatest measured capacity, separating an average of $20.3 \mathrm{~m}^{3}$ of slurry ma-
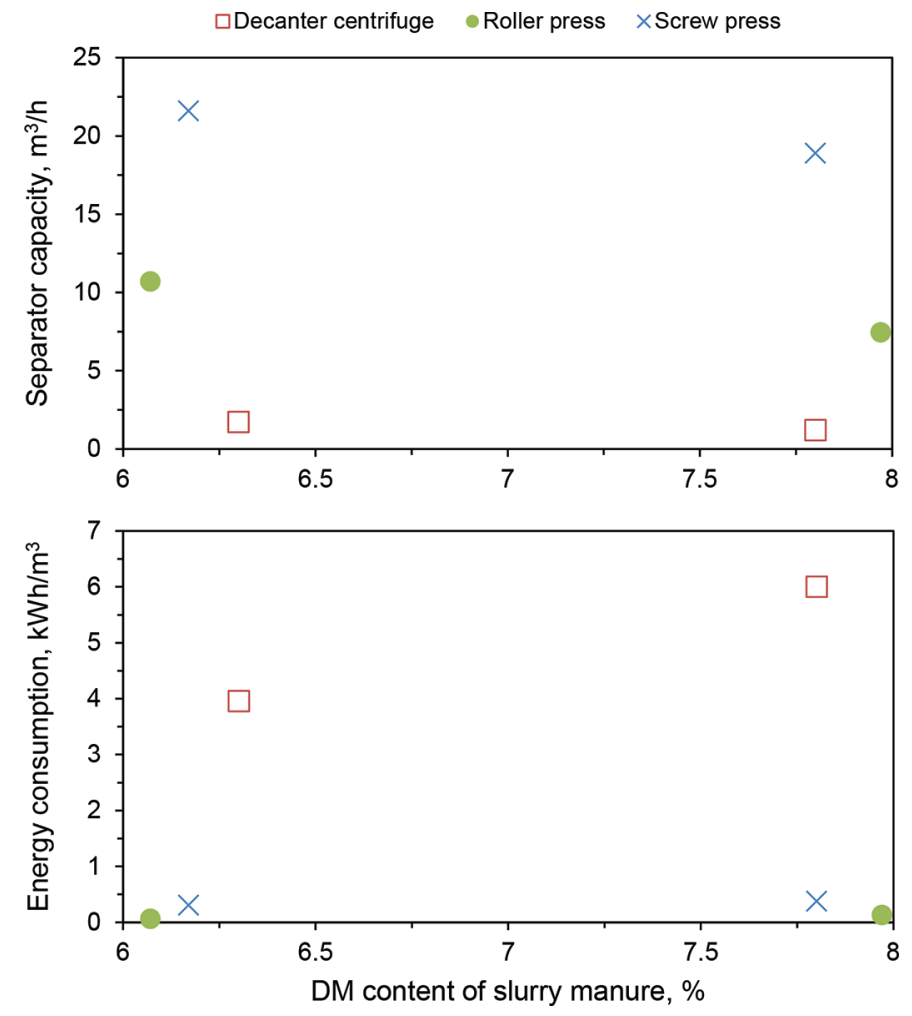

Figure 3. Influence of slurry DM content on the treatment capacity and energy consumption of the separator.

nure per hour (Table 2). The volume flow rate reached by the centrifuge $\left(1.5 \mathrm{~m}^{3} / \mathrm{h}\right)$ was about 14 times lower than the screw press. The roller press resulted in an intermediate capacity value $\left(9.1 \mathrm{~m}^{3} / \mathrm{h}\right)$. The influent flow rate data are consistent with other scientific works (Pos et al., 1984; Gooch et al., 2005; Wu, 2007) using a similar GEA roller press (5.9 to $20.4 \mathrm{~m}^{3} / \mathrm{h}$ ) and FAN screw press $\left(6.6\right.$ to $\left.22.0 \mathrm{~m}^{3} / \mathrm{h}\right)$ to separate dairy manure. Martin et al. (2006) tested the same centri-

Table 2. Average DM content, volume flow rates, and energy consumption for the different manure fractions from the tested decanter centrifuge (DC), roller press (RP), and screw press (SP)

\begin{tabular}{|c|c|c|c|c|c|c|}
\hline \multirow[b]{2}{*}{ Item } & \multicolumn{3}{|c|}{ Wk 1} & \multicolumn{3}{|c|}{ Wk 2} \\
\hline & $\mathrm{DC}$ & $\mathrm{RP}$ & SP & DC & $\mathrm{RP}$ & SP \\
\hline \multicolumn{7}{|c|}{ DM content, \% } \\
\hline Slurry & $6.30^{\mathrm{a}}$ & $6.07^{\mathrm{a}}$ & $6.17^{\mathrm{a}}$ & $7.80^{\mathrm{a}}$ & $7.97^{\mathrm{a}}$ & $7.80^{\mathrm{a}}$ \\
\hline Liquid & $4.03^{\mathrm{c}}$ & $5.43^{\mathrm{a}}$ & $5.00^{\mathrm{b}}$ & $4.23^{\mathrm{c}}$ & $6.60^{\mathrm{a}}$ & $5.20^{\mathrm{b}}$ \\
\hline Solids & $33.90^{\mathrm{a}}$ & $33.30^{\mathrm{a}}$ & $26.23^{\mathrm{b}}$ & $33.50^{\mathrm{a}}$ & $28.17^{\mathrm{b}}$ & $24.27^{\mathrm{c}}$ \\
\hline \multicolumn{7}{|c|}{ Volume flow rate, $\mathrm{m}^{3} / \mathrm{h}$} \\
\hline Slurry & 1.73 & 10.66 & 21.57 & 1.21 & 7.46 & 18.95 \\
\hline Liquid & 1.36 & 8.59 & 20.26 & 0.90 & 4.83 & 14.22 \\
\hline Solids & 0.37 & 0.58 & 3.86 & 0.51 & 1.16 & 6.98 \\
\hline \multicolumn{7}{|c|}{ Energy consumption, $\mathrm{kWh} / \mathrm{m}^{3}$} \\
\hline Slurry & 3.96 & 0.07 & 0.31 & 6.01 & 0.13 & 0.38 \\
\hline
\end{tabular}

${ }^{\mathrm{a}-c}$ Means within a row and a week with different superscripts differ $(P<0.05)$. 
fuge but with pig manure and obtained capacity values ranging between 1.2 and $2.5 \mathrm{~m}^{3} / \mathrm{h}$.

Table 2 shows that separating manure using centrifugal force is an energy-demanding process with an average of $4.99 \mathrm{kWh}$ consumed per cubic meter of slurry treated, whereas both mechanical presses worked properly with less than $0.38 \mathrm{kWh} / \mathrm{m}^{3}$. This is in agreement with the results of Møller et al. (2000) who showed that roller and screw separator energy consumption ranged between 0.11 and $0.53 \mathrm{kWh} / \mathrm{m}^{3}$.

Liquid and Solid Fractions. The initial DM difference affected the quality and production rate of liquid and solids since we detected a significant week effect $(P<0.05)$ for both effluent fraction DM percentages. In fact, during the second week, liquid DM content increased by 4 to $22 \%$, whereas solids DM content decreased by 1 to $15 \%$ (Table 2). The type of separator also affected the resulting DM content of liquid and solid parts $(P<0.001)$.

The liquid fraction produced by the centrifuge showed the lowest concentration of DM (4.13\% on average), followed by the screw press $(5.10 \%$ on average) and the roller press (6.02\% on average). Gooch et al. (2005) tested similar roller and screw separators on different farms and also achieved higher DM percentage in the liquid output of the roller press $(7.58 \%)$ than in that of the screw press (4.06-5.06\%). In studies involving other European decanter centrifuges, the liquid DM content reached 3.02 to $3.77 \%$ (Møller et al., 2002, 2007).

The screw press produced the wettest solid material with a DM content of $25.3 \%$ on average, far lower than the roller separator and the centrifuge, which reached DM concentrations higher than 30.7\%. Although these screw press results were comparable to values (21.6-25.3\%) stated in Møller et al. (2000), Gooch et al. (2005), and Wu (2007) with a similar separator, a higher percentage of DM in the solid fraction could have been reached with a newer version of the screw press. Actually, the removal of water from the solids was not optimal because the squeezing process was limited by the motor power. During the experiments, we were not able to put the maximum weight on the arm attachment without lugging the motor. According to the manufacturer, the new generation of the FAN PSS 2 unit is assembled with an electrical motor of 4.0 or $5.5 \mathrm{~kW}$. Such separators can be expected to reach DM concentrations between 28.0 and $36.0 \%$ (Valacon-Dairy, 2014), which would be comparable to the data obtained in the present study with the roller press and centrifuge. In the literature (Møller et al., 2002, 2007; Gooch et al., 2005), the DM values for these separators were comparable to those of the screw press (19.9-23.9\%).

Inversely to DM, liquid volume flow rate declined and solids volume flow rate increased as slurry became thicker (Table 2). The present results showed that 70 to $90 \%$ of the influent volume ended up in a liquid form, which is very comparable to the reported studies (Pos et al., 1984; Gooch et al., 2005; Wu, 2007). Consistently with the treatment capacity of the separator, liquid and solid volume flow rates were different between the separators.

\section{Physical Properties}

Bulk Density. Table 3 presents the physical characteristics of the slurry and liquid and solid effluents after separation with the decanter centrifuge, roller press, and screw press. We noted a significant week effect $(P$ $<0.001)$ for slurry manure density, ranging from an average of $983 \mathrm{~kg} / \mathrm{m}^{3}$ in wk 1 to $1,010 \mathrm{~kg} / \mathrm{m}^{3}$ in wk 2 . This variance may have been linked with the change in initial TS content in the influent slurry. Within a week, no significant difference $(P>0.05)$ was present between manure densities at the entrance of the separators.

Because we calculated liquid densities for each experimental test by the ratio of the liquid trailer weight

Table 3. Physical properties of the influent slurry manure before separation and the liquid and solid fractions after separation by a decanter centrifuge (DC), a roller press (RP), and a screw press (SP)

\begin{tabular}{|c|c|c|c|c|c|c|}
\hline \multirow[b]{2}{*}{ Item } & \multicolumn{3}{|c|}{ Wk 1} & \multicolumn{3}{|c|}{ Wk 2} \\
\hline & $\mathrm{DC}$ & $\mathrm{RP}$ & $\mathrm{SP}$ & $\mathrm{DC}$ & $\mathrm{RP}$ & $\mathrm{SP}$ \\
\hline \multicolumn{7}{|l|}{ Bulk density, $\mathrm{kg} / \mathrm{m}^{3}$} \\
\hline Slurry & $970.0^{\mathrm{a}}$ & $985.7^{\mathrm{a}}$ & $992.7^{\mathrm{a}}$ & $1,010.0^{\mathrm{a}}$ & $1,010.0^{\mathrm{a}}$ & $1,010.0^{\mathrm{a}}$ \\
\hline Liquid & $1,004.4$ & $1,036.6$ & $1,015.2$ & $1,157.4$ & $1,018.4$ & $1,029.9$ \\
\hline Solids & $302.0^{\mathrm{b}}$ & $260.7^{\mathrm{c}}$ & $362.7^{\mathrm{a}}$ & $273.3^{\mathrm{b}}$ & $289.0^{\mathrm{b}}$ & $376.3^{\mathrm{a}}$ \\
\hline \multicolumn{7}{|l|}{ Water absorption, g/100 g } \\
\hline Solids & $167.3^{\mathrm{a}}$ & $176.7^{\mathrm{a}}$ & $117.7^{\mathrm{b}}$ & $177.0^{\mathrm{a}}$ & $133.7^{\mathrm{b}}$ & $103.7^{\mathrm{c}}$ \\
\hline \multicolumn{7}{|l|}{ Porosity, \% } \\
\hline Solids & $68.6^{\mathrm{b}}$ & $75.2^{\mathrm{a}}$ & $70.3^{\mathrm{b}}$ & $73.2^{\mathrm{a}}$ & $76.2^{\mathrm{a}}$ & $73.0^{\mathrm{a}}$ \\
\hline
\end{tabular}

${ }^{\mathrm{a}-\mathrm{c}}$ Means within a row and a week with different superscripts differ $(P<0.05)$. 
and the liquid volume in the 1,000-L vessels, we did not run a statistical analysis for this parameter. However, the results demonstrate that liquid density was around $1,025 \mathrm{~kg} / \mathrm{m}^{3}$ for both presses, whereas it varied between 1,004 and $1,157 \mathrm{~kg} / \mathrm{m}^{3}$ for the centrifuge (Table 3 ). We consider that this important range is the result of an imprecise measure of the volume during centrifuge experiments. In fact, the high-speed rotation movement created by this separator generated turbulence in the liquid so that $1,000-\mathrm{L}$ containers were foam-filled. Although we waited until the next morning to measure the level inside the vessels, the foam never totally dissipated, which resulted in rough estimations of the volume.

The interaction between separator type and week was significant $(P<0.05)$ for RMS density. Within the first week, all separators were different $(P<0.05)$ with densities ranging from $261 \mathrm{~kg} / \mathrm{m}^{3}$ for the roller press to $363 \mathrm{~kg} / \mathrm{m}^{3}$ for the screw press. During the second week, the centrifuge and roller press had similar $(P>0.05)$ solid fraction densities (average of $281 \mathrm{~kg} / \mathrm{m}^{3}$ ), which were significantly lower $(P<0.001)$ than that of the screw press $\left(376 \mathrm{~kg} / \mathrm{m}^{3}\right)$. Overall, drier solid material had lower density (Figure 4).

Water Absorption. The statistical analysis exposed a significant $(P<0.01)$ separator by week interaction

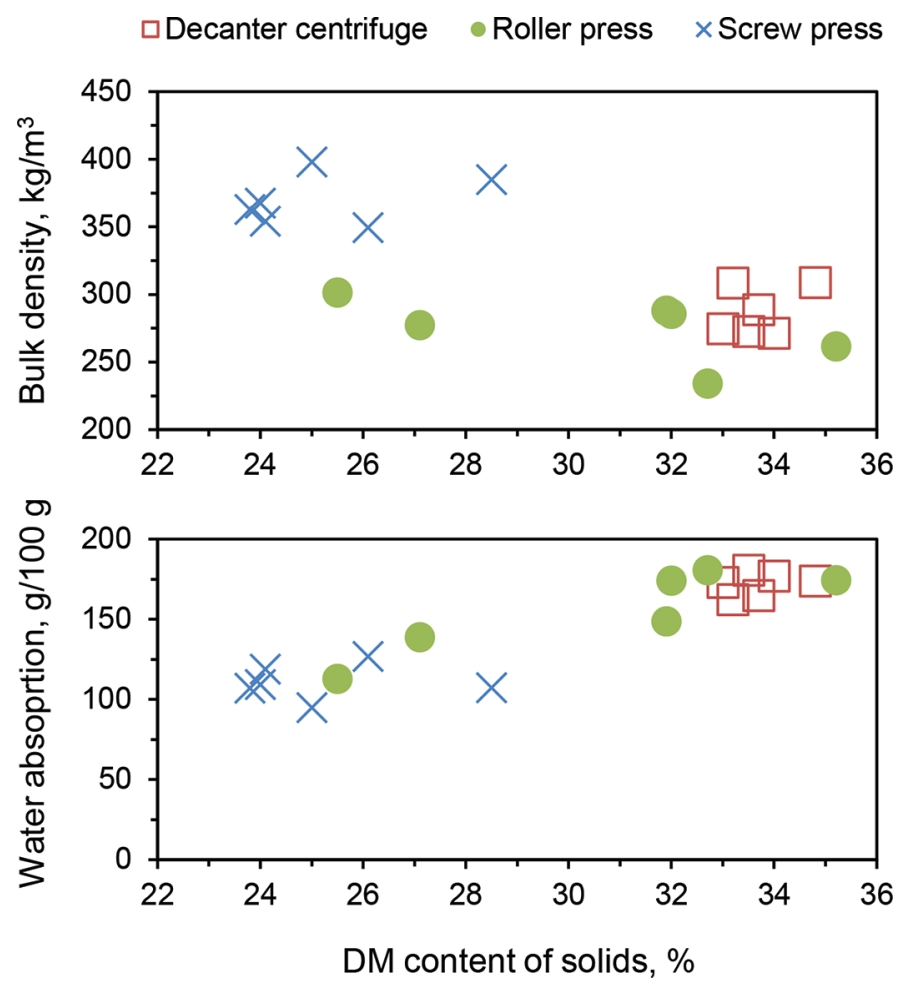

Figure 4. Influence of DM content on bulk density and water absorption of the solid fraction. for the water absorption property of the solid fraction. The comparisons between treatments within a week revealed that RMS from the screw press had the lowest $(P<0.01)$ absorption ratio $(104-118 \mathrm{~g} / 100 \mathrm{~g})$ during both weeks. Water absorption for the centrifuge $(167-177 \mathrm{~g} / 100 \mathrm{~g})$ and roller press $(134-177 \mathrm{~g} / 100 \mathrm{~g})$ was similar during wk $1(P>0.05)$ but different $(P<$ 0.001 ) during wk 2.

The RMS water retention capacity seemed to depend on DM content (Figure 4). In this context, RMS from the screw press would have reduced efficiency to remove moisture from the stall surface. However, we consider that a different result could have been obtained with a newer screw press model.

Porosity. The experiment series had a significant effect $(P<0.05)$ on porosity of RMS as the average for wk 1 and 2 were 71.4 and $74.1 \%$, respectively. The separator type also influenced $(P<0.05)$ the porosity of the solid material. Overall, the roller press had a greater porosity (average of $75.7 \%$ ) than that of the centrifuge and screw press (averages of 70.9 and $71.6 \%$ ).

According to the manufacturer, the roller press produced a fluffier material than any other separator. During the experiment, we noticed a difference in RMS texture between the roller press and the 2 other separators. The porosity results tended to confirm the manufacturer hypothesis.

Particle Size Distribution. The statistical analysis for each solids particle size category $(<1 \mathrm{~mm}, 1-4 \mathrm{~mm}$, and $>4 \mathrm{~mm})$ showed a significant separator effect $(P<$ $0.001)$. The centrifuge produced higher amounts of fine and medium particles than the other separators (Figure 5). In fact, the sieves under $4 \mathrm{~mm}$ retained $91.0 \%$ of the solid material from the centrifuge, compared with 35.3 and $28.6 \%$ for the roller and screw presses. Consequently, both presses generated a solid product with coarser particles as the majority of particles $(>62 \%)$ had a minimum diameter of $4 \mathrm{~mm}$.

Because finer particles composed most of centrifugemade RMS, their use as an alternative bedding for dairy cows could become problematic. Bernal et al. (2009) and Valacon-Dairy (2014) considered that very small particles may compact the mass, more readily hold moisture, and form a hard layer in the stalls. Harrison et al. (2008) also stipulated that when teat ends are exposed to wet and fine bedding, it is more likely to cause higher SCC and mastitis.

\section{Chemical Composition}

$p H$. The chemical characteristics of the major elements of the different fractions of dairy manure are given in Table 4. Values of $\mathrm{pH}$ for slurry and liquid products were 7.0 or slightly higher than neutrality, 


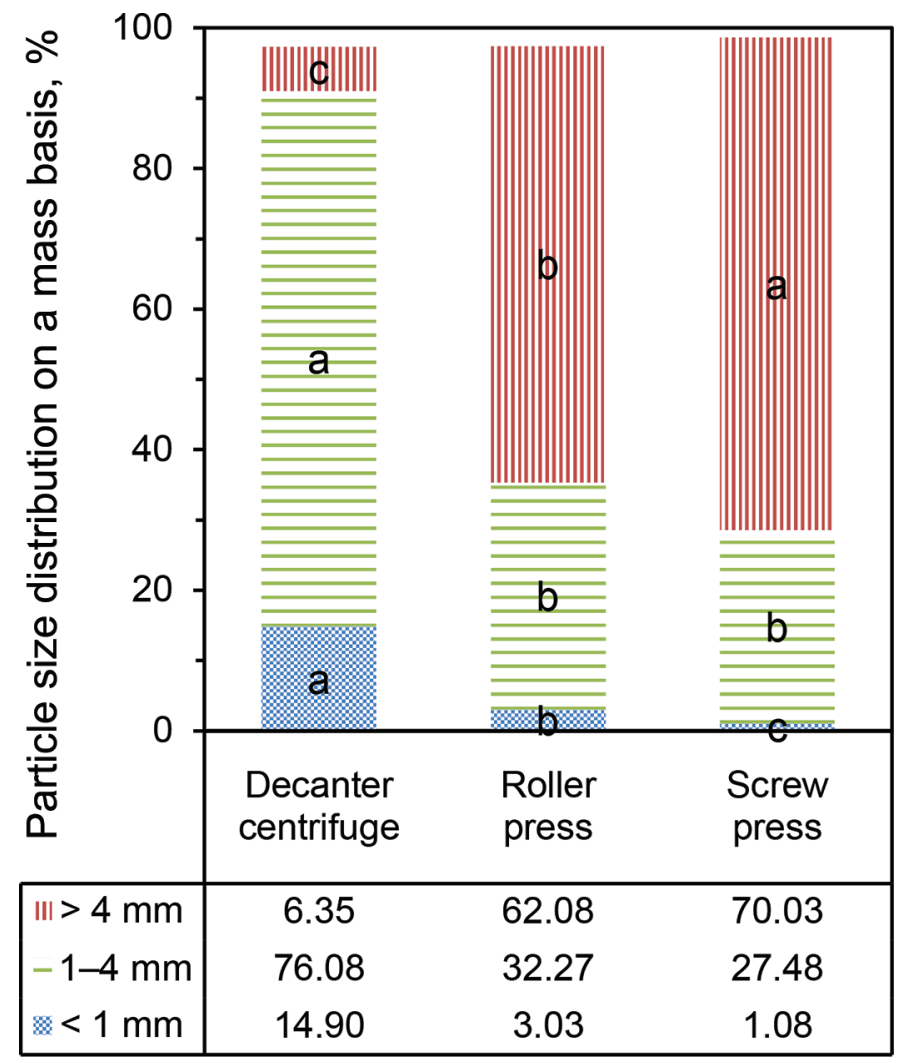

Figure 5. Particle size distribution of solids. Means within a particle size category with different letters $(\mathrm{a}-\mathrm{c})$ differ $(P<0.05)$.

whereas they reached between 8.5 and 9.0 in RMS. These results are comparable to the numbers reported by Møller et al. (2000), Møller et al. (2002), and Brito et al. (2008).

Ash, Organic Matter, and Carbon. Ash and OM concentrations in slurry influent manure were different $(P<0.001)$ between weeks $(21.7$ and $77.7 \%$ for wk 1 vs. 20.1 and $79.3 \%$ for wk 2 , respectively). The roller press resulted in lower $(P<0.001)$ ash content $(24.2-25.1 \%$ vs. $26.2-27.2 \%)$, and thus in higher $(P<0.05) \mathrm{OM}$ (74.9-75.8\% vs. $72.8-73.8 \%)$, in the liquid part than the centrifuge and screw press during both weeks. The decanter centrifuge produced RMS with the greatest $(P$ $<0.01)$ quantity of ash (13.6-14.7\%), followed by the screw press (9.0-11.1\%) and the roller press (6.6-9.0\%) in each test run. Consequently, centrifuge solids contained a smaller $(P<0.01)$ proportion of OM $(85.3-$ $86.4 \%)$ than that of the other separators (88.9-93.4\%). The solids separated with both presses had similar OM contents to those reported (89.7-90.5\%) by Brito et al. (2008).

Carbon amounts in slurry manure were significantly different $(P<0.001)$ between wk $1(390 \mathrm{~g} / \mathrm{kg}$ of DM) and wk $2(398 \mathrm{~g} / \mathrm{kg}$ of DM). After separation, the roller press produced the greatest $(P<0.01) \mathrm{C}$ concentration in the liquid (375-379 g/ $\mathrm{kg}$ of DM) and solid (455-467 $\mathrm{g} / \mathrm{kg}$ of DM) fractions during both weeks. Centrifuge and screw press produced a liquid fraction containing about 364 to $369 \mathrm{~g}$ of $\mathrm{C} / \mathrm{kg}$ of DM. For RMS, C amount at the exit of the centrifuge (426-432 $\mathrm{g} / \mathrm{kg}$ of DM) was lower $(P<0.01)$ than that of the screw press $(445-455$ $\mathrm{g} / \mathrm{kg}$ of DM).

Nitrogen. In slurry manure, total Kjeldahl nitrogen $(\mathbf{T K N}), \mathrm{NH}_{4}-\mathrm{N}$, and organic $\mathrm{N}(\mathbf{O N})$ varied $(P$ $<0.001)$ between weeks. These properties all dropped from wk 1 to 2 , from $58.3,24.6$, and $33.7 \mathrm{~g} / \mathrm{kg}$ of DM to $50.9,20.9$, and $29.8 \mathrm{~g} / \mathrm{kg}$ of DM, respectively.

In the separated liquid manure, we noted an interaction between separator and week affecting $(P<0.01)$ TKN, $\mathrm{NH}_{4}-\mathrm{N}$, and $\mathrm{ON}$ results. During both weeks, the centrifuge produced the liquid fraction with the highest concentration in each category $(82.0-84.7 \mathrm{~g}$ of TKN $/ \mathrm{kg}$ of DM, 38.3-40.3 g of $\mathrm{NH}_{4}-\mathrm{N} / \mathrm{kg}$ of DM, and 43.7-44.7 $\mathrm{g}$ of $\mathrm{ON} / \mathrm{kg}$ of $\mathrm{DM})$, followed by the screw press (70.7$73.7 \mathrm{~g}$ of $\mathrm{TKN} / \mathrm{kg}$ of $\mathrm{DM}, 32.7-34.7 \mathrm{~g}$ of $\mathrm{NH}_{4}-\mathrm{N} / \mathrm{kg}$ of $\mathrm{DM}$, and $38.3-39.0 \mathrm{~g}$ of $\mathrm{ON} / \mathrm{kg}$ of $\mathrm{DM})$ and the roller press $(58.3-64.0 \mathrm{~g}$ of $\mathrm{TKN} / \mathrm{kg}$ of DM, 22.7-24.7 $\mathrm{g}$ of $\mathrm{NH}_{4}-\mathrm{N} / \mathrm{kg}$ of DM, and 36.7-39.7 $\mathrm{g}$ of $\mathrm{ON} / \mathrm{kg}$ of DM).

A separator effect on $\mathrm{N}$ content $(P<0.05)$ was only observed for the solid fraction. The roller press and centrifuge respectively produced N-low and ON-rich RMS, whereas RMS from the screw press contained significantly $(P<0.001)$ more $\mathrm{NH}_{4}-\mathrm{N}(5.3 \mathrm{~g} / \mathrm{kg}$ of DM $)$ than that from the other separators $(<4.0 \mathrm{~g} / \mathrm{kg}$ of DM).

All TKN results were in accordance with the ranges (39.2-62.2, 46.1-103.4, and 7.9-29.6 $\mathrm{g} / \mathrm{kg}$ of DM for slurry, liquid, and solid manure, respectively) reported by several studies (Pos et al., 1984; Møller et al., 2000, 2002, 2007; Gooch et al., 2005). These works tended to demonstrate that the centrifuge produced an N-rich liquid manure, whereas the roller press had much less $\mathrm{N}$ in both separated fractions. In a study comparing mechanical presses identical to those used here, Gooch et al. (2005) also noticed reduced $\mathrm{NH}_{4}-\mathrm{N}$ concentrations in the separated fractions of the roller press.

Phosphorus and Potassium. The separation mechanism of $\mathrm{P}$ and $\mathrm{K}$, whose concentrations in slurry manure varied between 8.9 and $10.2 \mathrm{~g} / \mathrm{kg}$ of $\mathrm{DM}$ and 32.7 to $38.8 \mathrm{~g} / \mathrm{kg}$ of DM, respectively, due to a week effect $(P<0.001)$, differed between separators. With the centrifuge, most of the P ended up in the RMS (10.8 g/ $\mathrm{kg}$ of $\mathrm{DM})$, whereas the solid fraction from both presses only contained 3.7 to $5.2 \mathrm{~g} / \mathrm{kg}$ of DM $(P<0.05)$. In fact, during roller and screw separation, $\mathrm{P}$ was largely directed to the liquid phase where $\mathrm{P}$ levels $(>10.3 \mathrm{~g} /$ $\mathrm{kg}$ of $\mathrm{DM})$ are much higher $(P<0.001)$ than that of the centrifuge $(7.4 \mathrm{~g} / \mathrm{kg}$ of $\mathrm{DM})$. With similar initial $\mathrm{P}$ levels, the literature also suggests that a centrifugal 
process has the ability to concentrate $\mathrm{P}$ in the solid fraction. Møller et al. $(2002,2007)$ found 9.0 to $13.6 \mathrm{~g}$ of $\mathrm{P} / \mathrm{kg}$ of $\mathrm{DM}$ in centrifuged RMS, whereas a group of studies (Pos et al., 1984; Møller et al., 2000; Møller et al., 2002; Gooch et al., 2005; Wu, 2007) obtained 1.8 to $6.0 \mathrm{~g}$ of $\mathrm{P} / \mathrm{kg}$ of $\mathrm{DM}$ in pressurized RMS. These results highlighted that $\mathrm{P}$-based compounds are likely attached to fine particles that are a dominant fraction of RMS produced by centrifuge.

For $\mathrm{K}$, it was the opposite as a greater quantity $(P$ $<0.001$ ) of $\mathrm{K}$ was found in the liquid fraction of the centrifuge $(58.2-61.1 \mathrm{~g} / \mathrm{kg}$ of DM) than in that of both presses $(39.0-50.0 \mathrm{~g} / \mathrm{kg}$ of DM) during both weeks. Consequently, RMS from screw and roller presses $(7.0-8.7 \mathrm{~g} / \mathrm{kg}$ of $\mathrm{DM})$ retained more $\mathrm{K}(P<0.001)$ than the centrifuge $(6.1 \mathrm{~g} / \mathrm{kg}$ of $\mathrm{DM})$. However, overall, $\mathrm{K}$ tended to be present in greater amounts in the liquid phase because of its solubility, which is in accordance with the works of Gooch et al. (2005) and Møller et al. (2007).

Calcium and Magnesium. Concentrations of $\mathrm{Ca}(26.3-28.5 \mathrm{~g} / \mathrm{kg}$ of $\mathrm{DM})$ and $\mathrm{Mg}(9.8-11.5 \mathrm{~g} / \mathrm{kg}$ of

Table 4. Chemical properties of the influent slurry manure before separation and the liquid and solid fractions after separation by a decanter centrifuge (DC), a roller press (RP), and a screw press (SP)

\begin{tabular}{|c|c|c|c|c|c|c|}
\hline \multirow[b]{2}{*}{ Item } & \multicolumn{3}{|c|}{ Wk 1} & \multicolumn{3}{|c|}{ Wk 2} \\
\hline & $\mathrm{DC}$ & $\mathrm{RP}$ & $\mathrm{SP}$ & $\mathrm{DC}$ & $\mathrm{RP}$ & $\mathrm{SP}$ \\
\hline \multicolumn{7}{|l|}{$\overline{\mathrm{pH}}$} \\
\hline Slurry & $7.07^{\mathrm{b}}$ & $7.40^{\mathrm{a}}$ & $7.03^{\mathrm{b}}$ & $6.97^{\mathrm{b}}$ & $7.10^{\mathrm{a}}$ & $7.00^{\mathrm{b}}$ \\
\hline Liquid & $7.50^{\mathrm{a}}$ & $7.47^{\mathrm{a}}$ & $7.13^{\mathrm{b}}$ & $7.37^{\mathrm{a}}$ & $7.20^{\mathrm{b}}$ & $7.07^{\mathrm{c}}$ \\
\hline Solids & $8.70^{\mathrm{b}}$ & $9.00^{\mathrm{a}}$ & $8.47^{\mathrm{c}}$ & $8.47^{\mathrm{a}}$ & $8.57^{\mathrm{a}}$ & $8.50^{\mathrm{a}}$ \\
\hline \multicolumn{7}{|l|}{ Ash, \% } \\
\hline Slurry & $21.43^{\mathrm{b}}$ & $22.17^{\mathrm{a}}$ & $22.27^{\mathrm{a}}$ & $20.07^{\mathrm{b}}$ & $20.47^{\mathrm{ab}}$ & $20.73^{\mathrm{a}}$ \\
\hline Liquid & $26.77^{\mathrm{a}}$ & $25.10^{\mathrm{b}}$ & $26.20^{\mathrm{a}}$ & $27.07^{\mathrm{a}}$ & $24.23^{\mathrm{b}}$ & $27.17^{\mathrm{a}}$ \\
\hline Solids & $14.73^{\mathrm{a}}$ & $6.60^{\mathrm{c}}$ & $9.00^{\mathrm{b}}$ & $13.60^{\mathrm{a}}$ & $9.03^{\mathrm{c}}$ & $11.07^{\mathrm{b}}$ \\
\hline \multicolumn{7}{|l|}{ OM, \% } \\
\hline Slurry & $78.57^{\mathrm{a}}$ & $77.83^{\mathrm{ab}}$ & $77.73^{\mathrm{b}}$ & $79.97^{\mathrm{a}}$ & $79.57^{\mathrm{a}}$ & $79.30^{\mathrm{a}}$ \\
\hline Liquid & $73.23^{\mathrm{b}}$ & $74.90^{\mathrm{a}}$ & $73.80^{\mathrm{b}}$ & $72.97^{\mathrm{b}}$ & $75.77^{\mathrm{a}}$ & $72.80^{\mathrm{b}}$ \\
\hline Solids & $85.27^{\mathrm{c}}$ & $93.40^{\mathrm{a}}$ & $91.00^{\mathrm{b}}$ & $86.43^{\mathrm{c}}$ & $90.97^{\mathrm{a}}$ & $88.93^{\mathrm{b}}$ \\
\hline \multicolumn{7}{|c|}{$\mathrm{C}, \mathrm{g} / \mathrm{kg}$ of $\mathrm{DM}$} \\
\hline Slurry & $393.00^{\mathrm{a}}$ & $389.33^{\mathrm{ab}}$ & $388.33^{\mathrm{b}}$ & $399.67^{\mathrm{a}}$ & $397.67^{\mathrm{a}}$ & $396.33^{\mathrm{a}}$ \\
\hline Liquid & $366.33^{\mathrm{b}}$ & $374.67^{\mathrm{a}}$ & $368.67^{\mathrm{b}}$ & $365.00^{\mathrm{b}}$ & $379.00^{\mathrm{a}}$ & $364.00^{\mathrm{b}}$ \\
\hline Solids & $426.33^{\mathrm{c}}$ & $467.33^{\mathrm{a}}$ & $455.00^{\mathrm{b}}$ & $432.33^{\mathrm{c}}$ & $455.00^{\mathrm{a}}$ & $444.67^{\mathrm{b}}$ \\
\hline \multicolumn{7}{|c|}{ TKN ${ }^{1} \mathrm{~g} / \mathrm{kg}$ of DM } \\
\hline Slurry & $56.67^{\mathrm{b}}$ & $59.67^{\mathrm{a}}$ & $58.67^{\mathrm{a}}$ & $51.33^{\mathrm{a}}$ & $50.00^{\mathrm{a}}$ & $51.33^{\mathrm{a}}$ \\
\hline Liquid & $82.00^{\mathrm{a}}$ & $64.00^{\mathrm{c}}$ & $70.67^{\mathrm{b}}$ & $84.67^{\mathrm{a}}$ & $58.33^{\mathrm{c}}$ & $73.67^{\mathrm{b}}$ \\
\hline Solids & $18.00^{\mathrm{a}}$ & $14.33^{\mathrm{b}}$ & $18.33^{\mathrm{a}}$ & $19.00^{\mathrm{ab}}$ & $16.67^{\mathrm{b}}$ & $20.00^{\mathrm{a}}$ \\
\hline \multicolumn{7}{|c|}{$\mathrm{NH}_{4}-\mathrm{N}, \mathrm{g} / \mathrm{kg}$ of $\mathrm{DM}$} \\
\hline Slurry & $25.33^{\mathrm{a}}$ & $22.00^{\mathrm{b}}$ & $26.33^{\mathrm{a}}$ & $22.33^{\mathrm{a}}$ & $18.67^{\mathrm{b}}$ & $21.67^{\mathrm{a}}$ \\
\hline Liquid & $38.33^{\mathrm{a}}$ & $24.67^{\mathrm{c}}$ & $32.67^{\mathrm{b}}$ & $40.33^{\mathrm{a}}$ & $22.67^{\mathrm{b}}$ & $34.67^{\mathrm{c}}$ \\
\hline Solids & $3.00^{\mathrm{b}}$ & $2.67^{\mathrm{b}}$ & $5.67^{\mathrm{a}}$ & $4.00^{\mathrm{b}}$ & $3.67^{\mathrm{b}}$ & $5.33^{\mathrm{a}}$ \\
\hline \multicolumn{7}{|c|}{ Organic $\mathrm{N}, \mathrm{g} / \mathrm{kg}$ of $\mathrm{DM}$} \\
\hline Slurry & $31.33^{\mathrm{b}}$ & $37.33^{\mathrm{a}}$ & $32.33^{\mathrm{b}}$ & $28.67^{\mathrm{b}}$ & $31.33^{\mathrm{a}}$ & $29.33^{\mathrm{b}}$ \\
\hline Liquid & $43.67^{\mathrm{a}}$ & $39.67^{\mathrm{b}}$ & $38.33^{\mathrm{b}}$ & $44.67^{\mathrm{a}}$ & $36.67^{\mathrm{c}}$ & $39.00^{\mathrm{b}}$ \\
\hline Solids & $14.67^{\mathrm{a}}$ & $12.00^{\mathrm{b}}$ & $13.00^{\mathrm{ab}}$ & $15.00^{\mathrm{a}}$ & $13.00^{\mathrm{a}}$ & $14.33^{\mathrm{a}}$ \\
\hline \multicolumn{7}{|c|}{$\mathrm{P}, \mathrm{g} / \mathrm{kg}$ of $\mathrm{DM}$} \\
\hline Slurry & $9.93^{\mathrm{b}}$ & $10.23^{\mathrm{a}}$ & $10.23^{\mathrm{a}}$ & $9.43^{\mathrm{a}}$ & $8.93^{\mathrm{b}}$ & $9.13^{\mathrm{b}}$ \\
\hline Liquid & $7.47^{\mathrm{c}}$ & $11.00^{\mathrm{b}}$ & $11.63^{\mathrm{a}}$ & $7.30^{\mathrm{c}}$ & $10.30^{\mathrm{b}}$ & $11.63^{\mathrm{a}}$ \\
\hline Solids & $10.90^{\mathrm{a}}$ & $3.57^{\mathrm{c}}$ & $5.17^{\mathrm{b}}$ & $10.60^{\mathrm{a}}$ & $3.73^{\mathrm{c}}$ & $5.23^{\mathrm{b}}$ \\
\hline \multicolumn{7}{|c|}{$\mathrm{K}, \mathrm{g} / \mathrm{kg}$ of $\mathrm{DM}$} \\
\hline Slurry & 37.27 & 38.77 & 37.83 & 32.70 & 32.73 & 32.87 \\
\hline Liquid & $58.23^{\mathrm{a}}$ & $43.50^{\mathrm{c}}$ & $46.13^{\mathrm{b}}$ & $61.13^{\mathrm{a}}$ & $38.97^{\mathrm{c}}$ & $50.03^{\mathrm{b}}$ \\
\hline Solids & $5.53^{\mathrm{b}}$ & $6.10^{\mathrm{b}}$ & $7.87^{\mathrm{a}}$ & $6.67^{\mathrm{c}}$ & $7.97^{\mathrm{b}}$ & $9.60^{\mathrm{a}}$ \\
\hline \multicolumn{7}{|c|}{$\mathrm{Ca}, \mathrm{g} / \mathrm{kg}$ of $\mathrm{DM}$} \\
\hline Slurry & $26.30^{\mathrm{a}}$ & $28.07^{\mathrm{a}}$ & $28.47^{\mathrm{a}}$ & $28.43^{\mathrm{a}}$ & $26.57^{\mathrm{ab}}$ & $24.73^{\mathrm{b}}$ \\
\hline Liquid & $30.73^{\mathrm{b}}$ & $30.13^{\mathrm{b}}$ & $34.77^{\mathrm{a}}$ & $33.33^{\mathrm{a}}$ & $29.40^{\mathrm{b}}$ & $34.93^{\mathrm{a}}$ \\
\hline Solids & $19.00^{\mathrm{a}}$ & $8.93^{\mathrm{c}}$ & $11.67^{\mathrm{b}}$ & $20.37^{\mathrm{a}}$ & $12.73^{\mathrm{b}}$ & $13.60^{\mathrm{b}}$ \\
\hline \multicolumn{7}{|c|}{$\mathrm{Mg}, \mathrm{g} / \mathrm{kg}$ of $\mathrm{DM}$} \\
\hline Slurry & $11.10^{\mathrm{b}}$ & $11.53^{\mathrm{a}}$ & $11.43^{\mathrm{a}}$ & $10.00^{\mathrm{a}}$ & $9.83^{\mathrm{a}}$ & $9.93^{\mathrm{a}}$ \\
\hline Liquid & $11.03^{\mathrm{c}}$ & $12.47^{\mathrm{b}}$ & $13.33^{\mathrm{a}}$ & $10.83^{\mathrm{c}}$ & $11.47^{\mathrm{b}}$ & $13.30^{\mathrm{a}}$ \\
\hline Solids & $9.13^{\mathrm{a}}$ & $3.23^{\mathrm{c}}$ & $4.67^{\mathrm{b}}$ & $8.70^{\mathrm{a}}$ & $3.70^{\mathrm{c}}$ & $4.80^{\mathrm{b}}$ \\
\hline
\end{tabular}

${ }^{\mathrm{a}-\mathrm{c}}$ Means within a row and a week with different superscripts differ $(P<0.05)$.

${ }^{1}$ Total Kjeldahl nitrogen. 
DM) showed some variations in input slurry manure, but the separator effect was highly notable in the liquid and solid fractions $(P<0.001)$. The screw press seemed to direct slightly more $\mathrm{Ca}(34.9 \mathrm{~g} / \mathrm{kg}$ of $\mathrm{DM})$ and $\mathrm{Mg}(13.3 \mathrm{~g} / \mathrm{kg}$ of $\mathrm{DM})$ into the liquid phase than the other 2 separators (29.8-32.0 and 10.9-12.0 $\mathrm{g} / \mathrm{kg}$ of DM, respectively). The centrifuge produced RMS with contents of $\mathrm{Ca}(19.7 \mathrm{~g} / \mathrm{kg}$ of $\mathrm{DM})$ and $\mathrm{Mg}(8.9 \mathrm{~g} / \mathrm{kg}$ of DM) that were almost double those of the presses (10.8-12.6 and 3.5-4.7 $\mathrm{g} / \mathrm{kg}$ of DM, respectively).

\section{Bacteriological Composition}

No separator demonstrated superior efficiency to reduce slurry initial levels of E. coli (4.62-4.99 $\log _{10}$ $\mathrm{cfu} / \mathrm{g}$ of DM), Klebsiella spp. (4.14-4.58 $\log _{10} \mathrm{cfu} / \mathrm{g}$ of $\mathrm{DM})$, Enterococcus spp. (6.72-6.97 $\log _{10} \mathrm{cfu} / \mathrm{g}$ of DM), Staphylococcus spp. (6.08-6.68 $\log _{10} \mathrm{cfu} / \mathrm{g}$ of DM), and Streptococcus spp. (6.72-6.79 $\log _{10} \mathrm{cfu} / \mathrm{g}$ of DM) in either liquid or solid fractions (Table 5). Comparisons between separators for all bacteria also revealed no significant difference between liquid and solid counts $(P$ $>0.05)$. The microbiological distribution from slurry manure to liquid and solid effluents was generally homogeneous for the 3 separators as a difference of less than $1 \log _{10} \mathrm{cfu} / \mathrm{g}$ of DM was observed between both separated fractions.

These observations agreed with Liu et al. (2017) who reported negligible changes in $E$. coli counts in RMS sampled after centrifugation compared with un- separated dairy manure. These authors also stipulated that high centrifugation speed and long retention time should be considered to improve bacterial reduction in RMS. In a large-scale manure treatment system including drum screens, a clarifier, an anaerobic digester, a screw press, and a dissolved air floatation unit, Liu et al. (2016) measured stable E. coli levels in liquid fractions through the process, except for the anaerobic digester which significantly reduced bacterial counts. Therefore, the physical separation step did not induce significant changes in microbiological concentrations. For RMS, Leach et al. (2015) and Rowbotham and Ruegg (2016) reported similar E. coli, Klebsiella spp., and Strep. spp. levels. Leach et al. (2015) also presented lower enterococci and Staph. spp. counts than those presented in this study.

\section{Separation Efficiency}

The separator-week effect $(P<0.05)$ for DM, N, and $\mathrm{P}$ separation efficiency was noticeable (Table 6) because the separators always ranked in the same order (decanter centrifuge $>$ screw press $>$ roller press) even though the results during the second week were higher than those observed during the first week. The centrifuge recovered on average $42.5 \%$ of $\mathrm{DM}, 14.8 \%$ of $\mathrm{N}$, and $47.2 \%$ of $\mathrm{P}$ in the solid phase. These numbers were about 20 percentage units less in each category than those reported by Møller et al. (2002, 2007), who used other European centrifuges to separate dairy manure.

Table 5. Bacterial counts $\left(\log _{10} \mathrm{cfu} / \mathrm{g} \text { of } \mathrm{DM} \pm \mathrm{SD}\right)^{1}$ in the influent slurry manure before separation and the liquid and solid fractions after separation by a decanter centrifuge (DC), a roller press (RP), and a screw press (SP)

\begin{tabular}{|c|c|c|c|}
\hline \multirow[b]{2}{*}{ Item } & \multicolumn{3}{|c|}{ Separator } \\
\hline & $\mathrm{DC}$ & $\mathrm{RP}$ & SP \\
\hline \multicolumn{4}{|c|}{ Escherichia coli } \\
\hline Slurry & $4.62(0.16)$ & $4.90(1.12)$ & $4.99(0.71)$ \\
\hline Liquid & $4.97(0.13)$ & $5.01(1.06)$ & $5.46(1.02)$ \\
\hline Solids & $4.59(0.34)$ & $5.04(0.60)$ & $4.97(0.41)$ \\
\hline \multicolumn{4}{|c|}{ Klebsiella spp. } \\
\hline Slurry & $4.41(0.48)$ & $4.14(2.35)$ & $4.58(0.72)$ \\
\hline Liquid & $4.93(0.39)$ & $4.04(2.24)$ & $5.04(1.05)$ \\
\hline Solids & $4.23(0.37)$ & $4.95(1.31)$ & $4.92(0.46)$ \\
\hline \multicolumn{4}{|c|}{ Enterococcus spp. } \\
\hline Slurry & $6.91(0.30)$ & $6.72(0.37)$ & $6.97(0.16)$ \\
\hline Liquid & $7.10(0.15)$ & $6.87(0.23)$ & $7.25(0.56)$ \\
\hline Solids & $6.33(0.42)$ & $6.62(0.40)$ & $6.81(0.33)$ \\
\hline \multicolumn{4}{|c|}{ Staphylococcus spp. } \\
\hline Slurry & $6.67(0.41)$ & $6.08(0.60)$ & $6.68(0.75)$ \\
\hline Liquid & $7.07(0.34)$ & $6.28(0.63)$ & $6.84(1.23)$ \\
\hline Solids & $6.64(0.21)$ & $6.43(0.36)$ & $6.92(0.37)$ \\
\hline \multicolumn{4}{|c|}{ Streptococcus spp. } \\
\hline Slurry & $6.77(0.37)$ & $6.72(0.69)$ & $6.79(0.25)$ \\
\hline Liquid & $7.19(0.26)$ & $6.86(0.41)$ & $6.97(0.73)$ \\
\hline Solids & $6.77(0.53)$ & $6.71(0.49)$ & $6.69(0.36)$ \\
\hline
\end{tabular}

${ }^{1}$ Means within a row did not differ $(P>0.05)$. 
Table 6. Separation efficiency of DM, N, and P (\%) by a decanter centrifuge (DC), a roller press (RP), and a screw press (SP)

\begin{tabular}{|c|c|c|c|c|c|c|}
\hline \multirow[b]{2}{*}{ Item } & \multicolumn{3}{|c|}{ Wk 1} & \multicolumn{3}{|c|}{ Wk 2} \\
\hline & $\mathrm{DC}$ & $\mathrm{RP}$ & $\mathrm{SP}$ & $\mathrm{DC}$ & $\mathrm{RP}$ & $\mathrm{SP}$ \\
\hline$\overline{\mathrm{DM}}$ & $35.83^{\mathrm{a}}$ & $7.93^{\mathrm{c}}$ & $28.00^{\mathrm{b}}$ & $49.13^{\mathrm{a}}$ & $15.80^{\mathrm{c}}$ & $42.67^{\mathrm{b}}$ \\
\hline $\mathrm{N}$ & $13.34^{\mathrm{a}}$ & $1.93^{\mathrm{c}}$ & $8.70^{\mathrm{b}}$ & $18.30^{\mathrm{a}}$ & $5.23^{\mathrm{c}}$ & $16.50^{\mathrm{b}}$ \\
\hline $\mathrm{P}$ & $39.50^{\mathrm{a}}$ & $2.80^{\mathrm{c}}$ & $13.83^{\mathrm{b}}$ & $54.93^{\mathrm{a}}$ & $6.50^{\mathrm{c}}$ & $24.37^{\mathrm{b}}$ \\
\hline
\end{tabular}

${ }^{a-c}$ Means within a row and a week with different superscripts differ $(P<0.05)$.

The difference could be due to the separator used whose main function was not to separate animal manure.

The screw press produced RMS with 35.3, 12.6, and $19.1 \%$ of the total input of DM, N, and P, respectively. These results are more comparable to the literature as the respective separation efficiencies average 40.2, 13.2, and $12.2 \%$ (Converse et al., 2000; Møller et al., 2000, 2002; Gooch et al., 2005; Wu, 2007; Brito et al., 2008).

As highlighted by Cocolo et al. (2012), the roller press achieved low separation efficiencies, ranging between $3.6 \%$ for $\mathrm{N}$ to $11.9 \%$ for DM. However, Gooch et al. (2005) obtained results near 40 and $18 \%$ for DM and $\mathrm{N}$ with the same roller separator on a farm. Because the roller press used during the experiment was new, adjustments on a day-to-day basis could have helped in improving its separation efficiency.

\section{Fertilizing Quality of the Liquid Fraction}

Mechanical separation altered the agronomic value of the liquid fraction by modifying: (1) N, P, and $\mathrm{K}$ contents (Table 4) and $\mathrm{C} / \mathrm{N}$ and $\left(\mathrm{NH}_{4}-\mathrm{N}+\mathrm{NO}_{3}-\mathrm{N}\right) /$ TKN ratios (Table 7 ), which determine the fertilizing efficiency of total N; and (2) OM amount (Table 4) and cation balance (Table 7), all affecting long-term soil quality. Depending on separator type, the changes in the aforementioned properties could be major or trivial.

Because TKN concentration in the liquid part differed between treatments whereas $\mathrm{C}$ content remained similar (Table 4$), \mathrm{C} / \mathrm{N}$ results significantly varied for both weeks $(P<0.001$; Table 7$)$. The roller press had the greatest $\mathrm{C} / \mathrm{N}$ ratio (6.18 on average), followed by the screw press (5.08 on average) and the centrifuge (4.38 on average). In addition, the roller press showed the lowest $(P<0.001)$ ratio of $\left(\mathrm{NH}_{4}-\mathrm{N}+\mathrm{NO}_{3}-\mathrm{N}\right) / \mathrm{TKN}$ (0.39 on average; Table 7 ). Given that the coefficient of $\mathrm{N}$ efficiency is inversely related to $\mathrm{C} / \mathrm{N}$ and linearly related to $\left(\mathrm{NH}_{4}-\mathrm{N}+\mathrm{NO}_{3}-\mathrm{N}\right) / \mathrm{TKN}$, it was $10 \%$ higher for the screw press and the centrifuge ( 0.65 on average) than for the roller press (Table 8).

This difference may seem small, but can become important when combined with the effect of the separators on $\mathrm{P}$ content. Because the centrifuge showed a lower $\mathrm{P}$ amount in the liquid part than the other machines (Table 4), it ended the experiments with the highest $(P$ $<0.001) \mathrm{N} / \mathrm{P}$ ratio (Table 7 ). In this context, the liquid effluent from the centrifuge can supply a greater part of crop $\mathrm{N}$ requirements if manure spreading is limited by $\mathrm{P}$ concentration in soils. As an example, for corn silage grown in a soil of average $\mathrm{P}$ content and based on a recommendation of $40 \mathrm{~kg}$ of $\mathrm{P}_{2} \mathrm{O}_{5} /$ ha (CRAAQ, 2010), the centrifuge liquid fraction could supply approximately $145 \mathrm{~kg}$ of efficient $\mathrm{N}$, whereas that of both presses would provide a maximum of $80 \mathrm{~kg}$ of efficient $\mathrm{N}$ (Table 8). On the other hand, the application rate in $\mathrm{K}_{2} \mathrm{O}$ with the separated liquid from the centrifuge would be twice the recommended dose (90 kg/ha), whereas this threshold would generally be respected if any press is used for separation.

This excessive input in $\mathrm{K}_{2} \mathrm{O}$ with the centrifuge would be all the more problematic as the existing cation imbalance $(\mathrm{K} /(\mathrm{Ca}+\mathrm{Mg})$ ratio differs from 1.00 ; Table 7$)$ would cause a decrease in $\mathrm{Ca}$ and $\mathrm{Mg}$ intake by the crop. Therefore, use of the centrifuge liquid fraction for

Table 7. $\mathrm{C} / \mathrm{N},\left(\mathrm{NH}_{4}-\mathrm{N}+\mathrm{NO}_{3}-\mathrm{N}\right) /$ total Kjeldahl nitrogen $(\mathrm{TKN}), \mathrm{N} / \mathrm{P}$, and $\mathrm{K} /(\mathrm{Ca}+\mathrm{Mg})$ ratios for the liquid fraction from a decanter centrifuge (DC), a roller press (RP), and a screw press (SP)

\begin{tabular}{|c|c|c|c|c|c|c|}
\hline \multirow[b]{2}{*}{ Item } & \multicolumn{3}{|c|}{ Wk 1} & \multicolumn{3}{|c|}{ Wk 2} \\
\hline & DC & $\mathrm{RP}$ & SP & DC & $\mathrm{RP}$ & $\mathrm{SP}$ \\
\hline$\overline{\mathrm{C} / \mathrm{N}}$ & $4.47^{\mathrm{c}}$ & $5.87^{\mathrm{a}}$ & $5.23^{\mathrm{b}}$ & $4.30^{\mathrm{c}}$ & $6.50^{\mathrm{a}}$ & $4.93^{\mathrm{b}}$ \\
\hline$\left(\mathrm{NH}_{4}-\mathrm{N}+\mathrm{NO}_{3}-\mathrm{N}\right) / \mathrm{TKN}$ & $0.47^{\mathrm{a}}$ & $0.39^{\mathrm{b}}$ & $0.46^{\mathrm{a}}$ & $0.48^{\mathrm{a}}$ & $0.39^{\mathrm{b}}$ & $0.48^{\mathrm{a}}$ \\
\hline $\mathrm{N} / \mathrm{P}$ & $11.02^{\mathrm{a}}$ & $5.82^{\mathrm{c}}$ & $6.08^{\mathrm{b}}$ & $11.65^{\mathrm{a}}$ & $5.65^{\mathrm{c}}$ & $6.33^{\mathrm{b}}$ \\
\hline $\mathrm{K} /(\mathrm{Ca}+\mathrm{Mg})$ & $1.39^{\mathrm{a}}$ & $1.02^{\mathrm{b}}$ & $0.96^{\mathrm{c}}$ & $1.38^{\mathrm{a}}$ & $0.96^{\mathrm{c}}$ & $1.04^{\mathrm{b}}$ \\
\hline
\end{tabular}

${ }^{\mathrm{a}-\mathrm{c}}$ Means within a row and a week with different superscripts differ $(P<0.05)$. 
Table 8. Coefficient of $\mathrm{N}$ efficiency, contents of efficient $\mathrm{N}, \mathrm{P}_{2} \mathrm{O}_{5}$, and $\mathrm{K}_{2} \mathrm{O}$, and application rate of efficient $\mathrm{N}$ and $\mathrm{K}_{2} \mathrm{O}$ based on $40 \mathrm{~kg}$ of $\mathrm{P}_{2} \mathrm{O}_{5}$ for the liquid fraction of a decanter centrifuge (DC), a roller press (RP), and a screw press (SP)

\begin{tabular}{|c|c|c|c|c|c|c|}
\hline \multirow[b]{2}{*}{ Item } & \multicolumn{3}{|c|}{ Wk 1} & \multicolumn{3}{|c|}{ Wk 2} \\
\hline & $\mathrm{DC}$ & $\mathrm{RP}$ & SP & $\mathrm{DC}$ & $\mathrm{RP}$ & $\mathrm{SP}$ \\
\hline Efficient $\mathrm{N}, \mathrm{kg} / \mathrm{t}$ & 2.17 & 2.05 & 2.28 & 2.38 & 2.26 & 2.49 \\
\hline $\mathrm{P}_{2} \mathrm{O}_{5},{ }^{2} \mathrm{~kg} / \mathrm{t}$ & 0.62 & 1.23 & 1.20 & 0.64 & 1.40 & 1.24 \\
\hline $\mathrm{K}_{2} \mathrm{O},{ }^{3} \mathrm{~kg} / \mathrm{t}$ & 2.81 & 2.83 & 2.77 & 3.11 & 3.07 & 3.11 \\
\hline Efficient $\mathrm{N}$ for $40 \mathrm{~kg}$ of $\mathrm{P}_{2} \mathrm{O}_{5},{ }^{4} \mathrm{~kg} / \mathrm{ha}$ & 140.41 & 66.81 & 75.90 & 149.57 & 64.81 & 79.96 \\
\hline
\end{tabular}

${ }^{1}$ Coefficient of $\mathrm{N}$ efficiency for spring and summer, G2-G3 soil, and annual crops (CRAAQ, 2010).

${ }^{2} \mathrm{P}_{2} \mathrm{O}_{5}$ efficiency estimated at $90 \%$ (CRAAQ, 2010).

${ }^{3} \mathrm{~K}_{2} \mathrm{O}$ efficiency estimated at $100 \%$ (CRAAQ, 2010).

${ }^{4}$ Recommended dose for a soil with an intermediate P/Al Mehlich-3 (5.1 to 10\%) for corn silage (CRAAQ, 2010).

fertilizing crops intended to feed the cows could be an issue as a lack in $\mathrm{Ca}$ and $\mathrm{Mg}$ could respectively lead to milk fever and grass tetany (Thomas and Miner, 1996; Leduc and Robert, 1997).

Because preservation of soil health and soil fertility is related to the $\mathrm{C}$ balance, the roller press had a slight advantage over the screw press and the centrifuge as it produced a liquid with more $\mathrm{C}$ (Table 4 ). When reported on a wet basis, the roller press liquid contained 22.6 $\mathrm{kg} / \mathrm{t}$ of $\mathrm{C}$, whereas that of the centrifuge and the screw press reached between 15.1 and $18.7 \mathrm{~kg} / \mathrm{t}$ of $\mathrm{C}$. This corresponds to increases of 22 and $48 \%$, respectively.

\section{Separator Analysis}

Considering that separator type did not have a major influence on the chemical and bacteriological composition of the RMS produced, the choice of a separator for Canadian dairy producers should be based on cost capacity, energy use, separation efficiency, structure of RMS, and the fertilizing quality of the separated liquid. Canadian dairy producers should thus exclude decanter centrifuges because of uneconomical performances. The centrifuge used in this study obtained the lowest treatment capacity despite greatest acquisition cost and energy consumption. In addition, it produced structurefine RMS and a low-quality liquid manure that could lead to negative consequences for farm economics such as mastitis (Hauge et al., 2012; Fávero et al., 2015) and second-rate homegrown feed ingredients (Thomas and Miner, 1996; Leduc and Robert, 1997), respectively.

In comparison with the centrifuge, presses reached acceptable volume flow rates at a minimal operation cost and a satisfactory quality of products, but did not achieve recommended DM content in RMS (>34\%; Bradley et al., 2018). However, the roller press reached $33.3 \% \mathrm{DM}$ on the first week, suggesting adjustments as a function of the input properties during day-to-day operation could help approaching the desired value. The poor DM attained by the screw press for RMS (25\%) was the result of the model used in the light of data presented by Valacon-Dairy (2014) for a newer version of the same separator. After solid-liquid separation, common practices suggest that RMS can be used directly in stalls without treatment or subjected to a hygienization procedure before being placed under the cows (Harrison et al., 2008; Husfeldt et al., 2012; Cole, 2015). The second option would be unavoidable for screw-pressed RMS as produced here.

Roller presses are also flexible in terms of inputs (initial DM content and particle size distribution) and produce a fluffy solid material with ideal properties for bedding (comfort and drying potential). Nevertheless, their compression process seems to favor the passage of solids into the liquid fraction (Table 2) so that a greater quantity of slurry manure is needed to produce the same quantity of RMS than with screw presses.

In the conditions of the study, roller presses seemed to have the advantage. If a newer version of the screw press had been used, the conclusion would have been different.

\section{CONCLUSIONS}

Canadian dairy producers have an increasing interest in using RMS as a bedding material. To inform them on methods of obtaining high quality RMS, the operational performances and physical, chemical, and bacteriological characteristics of effluent liquid and solid fractions of 3 mechanical solid-liquid manure separators were investigated. The decanter centrifuge showed the best performances in reducing water content in the solid fraction, but its acquisition and operational cost per $\mathrm{m}^{3}$ of RMS produced were too high to consider the use of this type of separator on commercial dairy farms. Screw and roller presses were a better compromise between 
expenses, separation efficiency, and quality of the RMS produced. The low DM content of RMS produced with the screw press used in this study may limit direct use of the RMS without further processing. Consequently, part II of the series (Fournel et al., 2019) compares composting methods as subsequent treatment for the production of high quality RMS.

\section{ACKNOWLEDGMENTS}

This project was funded by the Canadian Agricultural Adaptation Program (2014-2019) of Agriculture and Agri-Food Canada (AAFC, Ottawa, ON, Canada). We also thank the financial support of the Fonds de recherche du Québec-Nature et technologies (FRQNT, Québec City, QC, Canada), Centre de Recherche en Sciences Animales de Deschambault (CRSAD, Deschambault, QC, Canada), and Université Laval (Québec City, QC, Canada). The authors gratefully acknowledge Research and Development Institute for the Agri-Environment (IRDA, Québec City, QC, Canada) that provided in-kind contributions for this study. We especially recognize the technical and professional support provided by research staff (Joahnn Palacios, Kathie Roseberry, Michel Noël, Christian Gauthier, Harold Dusablon, Mariette Sauvageau, Réjean Groleau, François Montambeault, Annie Dumas, Patrick Dubé, Michèle Grenier, and Marianne Villettaz Robichaud) in all organizations. We finally thank GEA Houle (Drummondville, QC, Canada) for the free use of their roller separator.

\section{REFERENCES}

Bernal, M. P., J. A. Alburquerque, and R. Moral. 2009. Composting of animal manures and chemical criteria for compost maturity assessment. A review. Bioresour. Technol. 100:5444-5453. https:// doi.org/10.1016/j.biortech.2008.11.027.

Bradley, A. J., K. A. Leach, S. C. Archer, J. E. Breen, M. J. Green, I. Ohnstad, and S. Tuer. 2014. Scoping study on the potential risks (and benefits) of using recycled manure solids as bedding for dairy cattle. DairyCo, Agriculture and Horticulture Development Board, Kenilworth, United Kingdom.

Bradley, A. J., K. A. Leach, M. J. Green, J. Gibbons, I. C. Ohnstad, D. H. Black, B. Payne, V. E. Prout, and J. E. Breen. 2018. The impact of dairy cows' bedding material and its microbial content on the quality and safety of milk-A cross sectional study of UK farms. Int. J. Food Microbiol. 269:36-45. https://doi.org/10.1016/ j.ijfoodmicro.2017.12.022.

Brito, L. M., J. Coutinho, and S. R. Smith. 2008. Methods to improve the composting process of the solid fraction of dairy cattle slurry. Bioresour. Technol. 99:8955-8960. https://doi.org/10.1016/ j.biortech.2008.05.005.

Christensen, M. L., K. V. Christensen, and S. G. Sommer. 2013. Solidliquid separation of animal slurry. Pages 105-130 in Animal Manure Recycling. S. G. Sommer, M. L. Christensen, T. Schmidt, and L. S. Jensen, ed. John Wiley \& Sons Ltd., Chichester, United Kingdom.

Cocolo, G., S. Curnis, M. Hjorth, and G. Provolo. 2012. Effect of different technologies and animal manures on solid-liquid separation efficiencies. J. Agric. Eng. 43:55-64. https://doi.org/10.4081/jae 2012.e9.

Cole, K. J. 2015. Bacterial counts in composted and fresh recycled dairy manure bedding. MS thesis. Animal Sciences, The Ohio State University, Columbus.

Converse, J. C., R. G. Koegel, and R. J. Straub. 2000. Nutrient separation of dairy manure. Pages 118-131 in Eighth International Symposium on Animal, Agricultural and Food Processing Wastes. American Society of Agricultural Engineers (ASAE), Des Moines, IA.

CRAAQ. 2010. Guide de référence en fertilisation du Québec (Quebec's reference guide in fertilization). 2 nd ed. Centre de référence en agriculture et agroalimentaire du Québec (CRAAQ), Ste-Foy, QC, Canada.

Fávero, S., F. V. R. Portilho, A. C. R. Oliveira, H. Langoni, and J. C. F. Pantoja. 2015. Factors associated with mastitis epidemiologic indexes, animal hygiene, and bulk milk bacterial concentrations in dairy herds housed on compost bedding. Livest. Sci. 181:220-230. https://doi.org/10.1016/j.livsci.2015.09.002.

Ford, M., and R. Fleming. 2002. Mechanical solid-liquid separation of livestock manure literature review. Ridgetown College, University of Guelph, Ridgetown, ON, Canada.

Fournel, S., S. Godbout, P. Ruel, A. Fortin, K. Duquette-Lozeau, V. Létourneau, M. Généreux, J. Lemieux, D. Potvin, C. Côté, C. Duchaine, and D. Pellerin. 2019. Production of recycled manure solids for use as bedding in Canadian dairy farms: II. Composting methods. J. Dairy Sci. 102:1847-1865. https://doi.org/10.3168/jds .2018-14967.

Garcia, A., and F. Diaz-Royón. 2014. Recycled manure solids as bedding. Accessed Jul. 17, 2018. http://articles.extension.org/pages/ 70319/recycled-manure-solids-as-bedding.

Godbout, S., R. Joncas, D.-Y. Martin, B. Beaulieu, M. Trudelle, S. Richard, M. Côté, and F. Léveillée. 2002. Évaluation des performances techniques des séparateurs mécaniques à lisier et de leur rapport efficacité/coût (Evaluation of the technical and economical performances of mechanical separators). Association de gestion des engrais organiques (AGEO) du bassin de la rivière Yamaska, St-Hyacinthe, QC, Canada.

Godden, S., R. Bey, K. Lorch, R. Farnsworth, and P. Rapnicki. 2008. Ability of organic and inorganic bedding materials to promote growth of environmental bacteria. J. Dairy Sci. 91:151-159. https: //doi.org/10.3168/jds.2007-0415.

Gooch, C. A., S. F. Inglis, and K. J. Czymmek. 2005. Mechanical solid-liquid manure separation: performance evaluation on four New York State dairy farms-A preliminary report in Proc. 2005 ASAE Annual International Meeting American Society of Agricultural Engineers (ASAE), Tampa, FL

Harrison, E., J. Bonhotal, and M. Schwarz. 2008. Using manure solids as bedding. Cornell Waste Management Institute, Ithaca, NY.

Hauge, S. J., C. Kielland, G. Ringdal, E. Skjerve, and O. Nafstad. 2012. Factors associated with cattle cleanliness on Norwegian dairy farms. J. Dairy Sci. 95:2485-2496. https://doi.org/10.3168/ jds.2011-4786.

Hjorth, M., K. V. Christensen, M. L. Christensen, and S. G. Sommer. 2010. Solid-liquid separation of animal slurry in theory and practice. A review. Agron. Sustain. Dev. 30:153-180. https://doi.org/ 10.1051/agro/2009010

House, H. K. 2012. Bedding alternative. Pages $32-34$ in The Milk Producer. Vol. 88.

House, H. K. 2016. Using separated manure solids for compost bedding. Accessed Jul. 17, 2018. http://www.omafra.gov.on.ca/ english/engineer/facts/15-019.htm.

Husfeldt, A. W., M. I. Endres, J. A. Salfer, and K. A. Janni. 2012. Management and characteristics of recycled manure solids used for bedding in Midwest freestall dairy herds. J. Dairy Sci. 95:21952203. https://doi.org/10.3168/jds.2011-5105.

Katers, J. F., J. M. Schultz, and J. Roach. 2003. Solids separation of dairy manure. Biocycle 44:51-54.

Leach, K. A., S. C. Archer, J. E. Breen, M. J. Green, I. C. Ohnstad, S. Tuer, and A. J. Bradley. 2015. Recycling manure as cow bedding: 
Potential benefits and risks for UK dairy farms. Vet. J. 206:123130. https://doi.org/10.1016/j.tvjl.2015.08.013.

Leduc, R., and L. Robert. 1997. Alimentation: Spécial K (Feeding: Special K). Pages 38-40 in Le producteur de lait québécois. Vol. April.

Liu, Z., Z. S. Carroll, S. C. Long, A. Roa-Espinosa, and T. Runge. 2017. Centrifuge separation effect on bacterial indicator reduction in dairy manure. J. Environ. Manage. 191(Supplement C):268274. https://doi.org/10.1016/j.jenvman.2017.01.022.

Liu, Z., M. Sharara, S. Gunasekaran, and T. Runge. 2016. Effects of large-scale manure treatment processes on pathogen reduction, protein distributions, and nutrient concentrations. T. ASABE 59:695-702. https://doi.org/10.13031/trans.59.11227.

Martin, D.-Y., F. Léveillée, C. Landry, and R. Carrier. 2006. Installation et essais à la ferme d'un système de séparation solide-liquide du lisier de porcs complémenté par la stabilisation et l'entreposage de la fraction solide (Installation and on-farm testing of a solidliquid pig manure separation system and storage of the stabilized solid fraftion). Research and Development Institute for the Agric.Environment (IRDA), Québec City, QC, Canada.

Meyer, D. J., L. L. Timms, L. Moody, and R. Burns. 2007. Recycling digested manure solids for dairies. in Proc. Sixth International Dairy Housing Conference. American Society of Agricultural and Biological Engineers (ASABE), Minneapolis, MN.

Møller, H. B., J. D. Hansen, and C. A. G. Sørensen. 2007. Nutrient recovery by solid-liquid separation and methane productivity of solids. Trans. ASABE 50:193-200. https://doi.org/10.13031/2013 .22400 .

Møller, H. B., I. Lund, and S. G. Sommer. 2000. Solid-liquid separation of livestock slurry: efficiency and cost. Bioresour. Technol 74:223-229. https://doi.org/10.1016/S0960-8524(00)00016-X.
Møller, H. B., S. G. Sommer, and B. K. Ahring. 2002. Separation efficiency and particle size distribution in relation to manure type and storage conditions. Bioresour. Technol. 85:189-196. https:// doi.org/10.1016/S0960-8524(02)00047-0.

Pos, J., R. Trapp, and M. Harvey. 1984. Performance of a brushed screen/roller press manure separator. T. ASAE 27:1112-1118.

Rowbotham, R. F., and P. L. Ruegg. 2016. Bacterial counts on teat skin and in new sand, recycled sand, and recycled manure solids used as bedding in freestalls. J. Dairy Sci. 99:6594-6608. https:// doi.org/10.3168/jds.2015-10674.

Sorter, D. E., H. J. Kester, and J. S. Hogan. 2014. Bacterial count in recycled manure solids bedding replaced daily or deep packed in freestalls. J. Dairy Sci. 97:2965-2968. https://doi.org/10.3168/ jds.2013-7814

Thomas, E. D. and W. H. Miner. 1996. Fertilizing forages. In Dairy Day at Miner Institute. The William H. Miner Agricultural Research Institute, Chazy, NY.

Timms, L. L. 2008. Preliminary evaluation of separated manure solids characteristics at the new ISU dairy. No. Animal Industry Report: AS 654, ASL R2318. Iowa State University, Ames.

Valacon-Dairy. 2014. Recycled manure solids (RMS) as biobedding in cubicles for dairy cattle. Considerations and tips for practice. Accessed Jul. 17, 2018. http://www.keydollar.eu/wp-content/ uploads/2014/09/Biobedding-English-version.pdf.

$\mathrm{Wu}, \mathrm{Z}$. 2007. Phosphorus and nitrogen distribution of screw press separated dairy manure with recovery of bedding material. Appl. Eng. Agric. 23:757-762.

Zhang, R. H., and P. W. Westerman. 1997. Solid-liquid separation of animal manure for odor control and nutrient management. Appl. Eng. Agric. 13:657-664. 